UDC 631.356.26

\title{
THE RESULTS OF ROOT CROP CLEANER EXPERIMENTAL RESEARCH
}

\section{Viktor Baranovsky'; Viktor Tesliuk²; Vasil Lukach³; Mikola Ikalchyk³; Anatoly Kushnirenko ${ }^{3}$; Vasil Kulyk ${ }^{3}$}

\author{
${ }^{I}$ Ternopil Ivan Puluj National Technical University, Ternopil, Ukraine \\ ${ }^{2}$ National University of Life and Environmental Sciences of Ukraine, \\ Kyiv, Ukraine \\ ${ }^{3}$ University of Bioresearches and Nature Management of Ukraine «Nizhyn \\ Agrotechnical Institute», Nizhyn, Ukraine
}

\begin{abstract}
Summary. This article contains the results of the experimental research on the quantity of root tubers let through to the creasing rollers through the clearance between the worm screw and the feeding transporter working branch in the combined root crop cleaner. It also describes the experimental set and the technique used for dummy tuber root transportation research, with the size of root tubers $0.05 ; 0.1 ; 0.15$ and $0.2 \mathrm{~m}$ in diameter. The experimental research has been held basing on the PFE $2^{4}$ type planned experiment realisation. The variable factors were transporter speed (variation extremes of $1.2 \ldots 1.8 \mathrm{~m} / \mathrm{s}$ ), worm pitch (variation extremes of $0.5 \ldots 0.7$ $m$ ), clearance gap between the worm screw and transporter (variation extremes of $0.05 \ldots 0.1 \mathrm{~m}$ ), worm screw angle speed (variation extremes of $7 \ldots 15 \mathrm{rad} / \mathrm{s}$ ). The work provides the regression equations that characterize the dependency of the amount or tubers being let through the worm screw to the creasing rollers from the size characteristics of fodder beet root tubers. A graphic dependency analysis has been held and it set the root crop cleaner parameter and work modes best for the maximum quantity of root tubers ran through the device.

Key words: screw, feeding transporter, creasing rollers, quantity of root tubers let through the device.
\end{abstract}

Statement of the problem. In order to intensify the technological process of grass and soil separation, as well as beet topping during mechanized harvesting a constructional layout scheme of a combined root crop cleaner has been designed [1,2].

The peculiarity of the proposed tuber root crop cleaner technological process lies in that simultaneously to the soil and grass fossils being separated from the from the root tubers (Fig. 1 ), as a result of partial filtration of the small fossils through gaps between rods 3 of the feeding transporter 2 and further transportation of the unfiltered fossils through the clearance gap $H_{1}$, which is situated between the transporter working branch and the lower combing cylindrical roller 6 , a technological operation of beet topping takes place, with the help of two creasing rollers that rotate towards each other $[3,4]$.

The increase of root crop cleaner technological effectivity which lies in further reduction of dirt and grass fossils collecting in the machine is a relevant agricultural problem. The extent of tuber root topping, in the first place, depends on the quantity of root tubers that run through the worm screw to the clearance gap $H_{1}$ and arrive to the creasing rollers working zone $[5,6]$.

Analysis of the results received from the experimental research on the quantity of root tubers running to the creasing rollers will allow us optimize the rational constructive-cinematic parameters of the root crop cleaner constructive parts, with the values of which the quantity of the root tubers running through the worm to te creasing rollers will be maximal, taking other characteristics of its work qualities into account as well. 


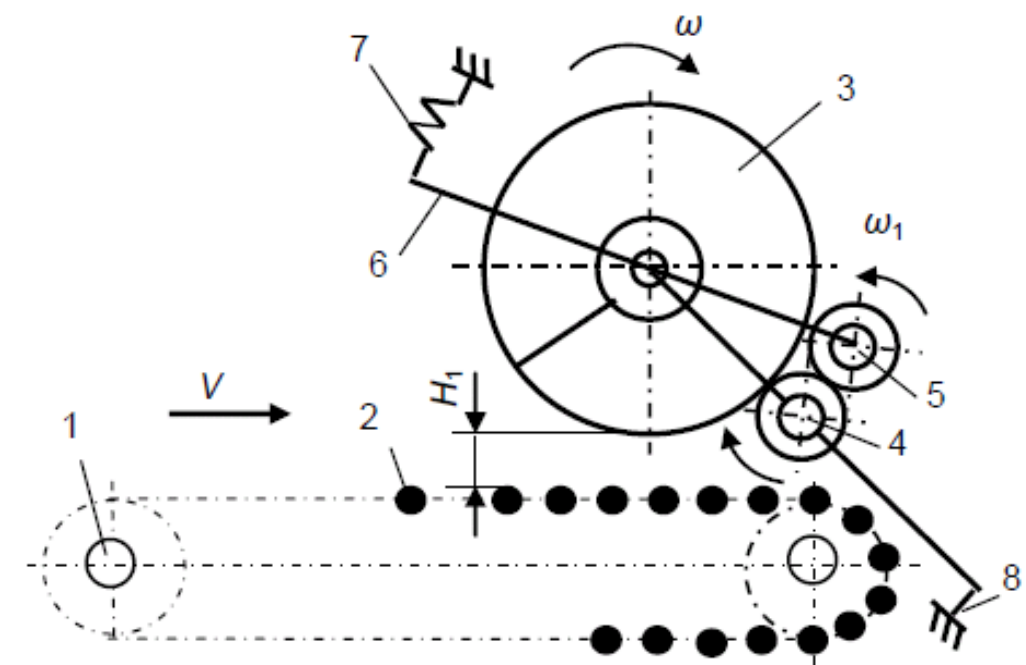

Figure 1. The constructive layout of a combined root crop cleaner, side view: 1 -feeding transporter; 2 -rod; 3 -worm screw; 4, 5 respectively - upper and lower creasing rollers; 6 -leverage; 5 - spring; $8-$ jamb

Analyses of available investigations. The undertaken theoretical and experimental research has been, as a rule, [7-14] related to setting the character and patterns of the contact interaction process between the root tubers and the combined root crop cleaner surface. The analysis of relevant publications in this sphere showed that the question of the quantity of tubers passing through to the creasing rollers has not been revealed, and any thorough research in this field is absent, consequently, this is what led to conducting such experimental research.

Statement of the problem. The research aim is substantiating the constructivecinematic parameters of the root crop cleaner operational parts basing on the analysis of the received empirical regularities of the quantity of root tubers being fed to the creasing rollers.

Materials and methods.The technological combined tuber root crop cleaner work process effectiveness, apart from separation from soil and plant fossils, also highly depends on the quality and extent of tuber topping by rubbing leaves from the beet head [4, 15-20]. At the same time, the extent of topping can be directly expressed with the quantity of tubers $K_{n}^{(i)}$ passing through the worm screw 3 (Fig. 1) to the clearance gap $H_{1}$ and to the creasing rollers 4, 5 in the combined tuber root crop cleaner.

For this research a set of dummy tubers was made, with the diameter $d_{k}=0.05 ; 0.1$; $0.15 ; 0.2 \mathrm{~m}$. During the experiment, the creasing rollers 4,5 (Fig. 1) have been dismantled from the device. The number of dummy tubers that had the same diameter was the following: tuber diameter 0.05 and $0.1 \mathrm{~m}-20$ pieces, tuber diameter 0.15 and $0.2 \mathrm{~m}-10$ pieces. During the mixed research the dummy models had the following proportions: diameter of $0.05 \mathrm{~m}-$ 5 pieces; diameter of $0.1 \mathrm{~m}-7$ pieces; $0.15 \mathrm{~m}-6$ pieces; $0.2 \mathrm{~m}-2$ pieces.

For the mixed research, the numerical proportion of tuber diameter has been defined based on the crop yields and root tuber size-mass characteristics.

The transportation of dummy tubers to the worm screw 3 was being carried out by the transporter 1, the speed of which $V$ was $1.2-1.5-1.8 \mathrm{~m} / \mathrm{s}$.

The angle speed of worm screw $\omega$ ranged from 7 to $15 \mathrm{rad} / \mathrm{s}$, the worm pitch $T$ was 0.5 and $0.7 \mathrm{~m}$.

The value of the radial clearance $H_{1}$ between the worm and working branch of the 
feeding transporter was equal to $0 ; 0.05 ; 0.1 \mathrm{~m}$.

On the first stage of optimization parameter research, or the quantity of tubers $K_{n}^{(i)}$ passing to the creasing rollers, a set of elimination experiments has been held to define the factors that do not significantly influence the value $K_{n}^{(i)}$, and the diameter of the screw $D$ does not implement a significant change to the quantity of passing tubers $K_{n}^{(i)}$, when the height of worm spiral $h$ is bigger than dummy diameter $d_{k}$, that is $D-d \geq d_{k}$, where $d$-is the diameter of the worm screw drum.

Apart from that it has been defined that with increase of worm rounds number $z$ the value $K_{n}^{(i)}$ proportionally decreases.

That is why, further experiments were held with $D=0.6 \mathrm{~m} ; h=0.2 \mathrm{~m}$ and $z=1$.

In order to define the influence of the main factors on the amount of tubers $K_{n}^{(i)}$ passing to the creasing rollers, a planned factorial experiment of a PFE 24 type has been held, that is, a 4 factor experiment with two levels of factor variation, while the entry variable factors were:

- feeding transporter speed $V$, which was coded with $x_{1}$ index;

- worm screw pitch $T$, coded with $x_{2}$ index;

- radial clearance between worm and working branch of the feeding transporter $H_{1}$, coded with $x_{3}$ index;

- worm screw angle speed $\omega$, coded with $x_{4}$ index.

The experiments were carried out in triplicate.

Factor characteristics and their variation levels are provided in the table 1.

Table 1

Factor characteristics and their variation levels

\begin{tabular}{|c|c|c|}
\hline Factor code mark & Factor name & Factor level \\
\hline$x_{1}$ & Transporter motion speed $V, \mathrm{~m} / \mathrm{s}$ & $1.2-1.8$ \\
\hline$x_{2}$ & Worm screw pitch $T, \mathrm{~m}$ & $0.5-0.7$ \\
\hline$x_{3}$ & Clearance gap between worm and transporter $H_{1}, \mathrm{~m}$ & $0-0.1$ \\
\hline$x_{4}$ & Worm screw angle speed $\omega, \mathrm{rad} / \mathrm{s}$ & $7-15$ \\
\hline
\end{tabular}

The approximation function for the experimental data pool concerning the quantity of tubers let through, written with a functional $K_{n}^{(i)}=f_{k}\left(V ; T ; H_{1} ; \omega\right)$, has been defined by sweeping through the available algebraic functions with the largest number determination $D$ value.

Statistic analysis results show that the highest value of number determination coefficient $D=0.987$ corresponds to a quadratic function. Thus, the feedback (optimization parameter) that describes the change character of tubers let to the creasing rollers quantity $K_{n}^{(i)}$, defined in an experimental way, has been defined as a mathematical model of a second degree total polynomial.

The second degree total polynomial regression equation has been defined with the results of statistic treatment of experimental data using the Statistica 10 computer software. 
Function variability has been defined by standard deviations, with the $D$ number determination coefficient and correlation coefficient.

Model adequacy and value of regression equation coefficients have been defined with the Fisher F-criterion and Student's t-criterion.

Results and discussion. The statistic treatment of experimental data pool led to obtaining final empirical regression equations that characterize the dependency of root tubers let to the creasing rollers quantity $K_{n}^{(i)}$ from the change of four factors for concretized root tuber diameters:

$$
\begin{gathered}
K_{n}^{(50)}=-57.6+63.5 \mathrm{~V}+1.1 H_{1}+10.2 \omega-11.6 V^{2}-0.3 V H_{1}-0.4 \omega^{2} ; \\
K_{n}^{(100)}=-190.8+174.2 V+0.9 H_{1}+15.8 \omega-56.3 V^{2}+V \omega-0.7 \omega^{2} ; \\
K_{n}^{(150)}=-91.6+100.3 V+0.5 H_{1}+6.8 \omega-30.4 V^{2}-0.3 \omega^{2} ; \\
K_{n}^{(200)}=-60.4+42.0 V+0.1 H_{1}+7.4 \omega-12.2 V^{2}-0.3 \omega^{2} .
\end{gathered}
$$

Regression equation analysis (1)-(4) shows that worm screw pitch $T$ does not influence the quantity of tubers let through to the creasing rollers $K_{n}^{(i)}$ by reason of factor $T$ being absent, i.e. regression equation (1)-(4) with $T$ factor after being tested with the Student's $t$-criterion are considered inessential and disregarded.

According to the regression equations (1)-(4) a feedback surface has been built as well as a feedback surface lateral cut, depicting the dependency of tubers let to the creasing rollers $K_{n}^{(i)}$ quantity from transporter motion speed $V$ and worm screw angle speed $\omega$ in the frame of factor variation:

- transporter motion speed $1.2 \leq V \leq 1.8 \mathrm{~m} / \mathrm{s}$;

- worm screw angle speed $7 \leq \omega \leq 15 \mathrm{rad} / \mathrm{s}$;

- radial clearance gap value $H_{1}=0.05 \mathrm{~m}$.

Graphic dependency analysis of the data provided on Fig. 2, Fig. 3 shows that the maximum value of tubers let through to the creasing rollers $K_{n}^{(i)}=\max$ is:

- for the roots with diameter $d_{k}=0.05 \mathrm{~m}-84 \%$ (Fig. 2 a);

- for the roots with diameter $d_{k}=0.1 \mathrm{~m}-52 \%$ (Fig. $2 \mathrm{~b}$ );

- for the roots with diameter $d_{k}=0.15 \mathrm{~mm}-30 \%$ (Fig. $3 \mathrm{a}$ );

- for the roots with diameter $d_{k}=0.2 \mathrm{~mm}-21 \%$ (Fig. $3 \mathrm{~b}$ ).

The justification of combined root crop cleaner must be held with the condition of concretized diameter root tuber maximum quantity $K_{n}^{(i)}$ being let through the worm screw to the creasing rollers, as far as the $K_{n}^{(i)}$ criterion value influences the degree of tuber topping that is total fossil decrease in the root crop in a direct ratio.

The change of $K_{n}^{(i)}$ depending on transporter speed $V$ and worm angle speed $\omega$ has the following character:

- for root tuber with $d_{k}=0.05 \mathrm{~m}$ diameter:

- with $V$ increase from 1.2 to $1.8 \mathrm{~m} / \mathrm{s}$ and worm screw angle speed between $7 \leq \omega \leq$ 
$13 \mathrm{rad} / \mathrm{s}$ the root tuber quantity $K_{n}^{(0.05)}$ grows monotonously (Fig. 2 a);

- the maximum quantity of roots let through to the creasing rollers can be reached when $V=1.8 \mathrm{~m} / \mathrm{s}$ and $\omega \geq 10 \mathrm{rad} / \mathrm{s}$

- for root tuber with $d_{k}=0.1,0.15$ and $0.2 \mathrm{~m}$ diameter: with transporter speed increase within $1.2 \leq V \leq 1.6 \mathrm{~m} / \mathrm{s}$ and worm screw angle speed within $7 \leq \omega \leq 12 \mathrm{rad} / \mathrm{s}$ the root tuber quantity $K_{n}^{(0.1)}$ (Fig. 2 b), $K_{n}^{(0.15)}$ (Fig. 3 a) and $K_{n}^{(0.2)}$ (Fig. 3 b) let through to the creasing rollers monotously grows for the corresponding concretized root diameter values can

- be reached with the following factor combinations respectively:
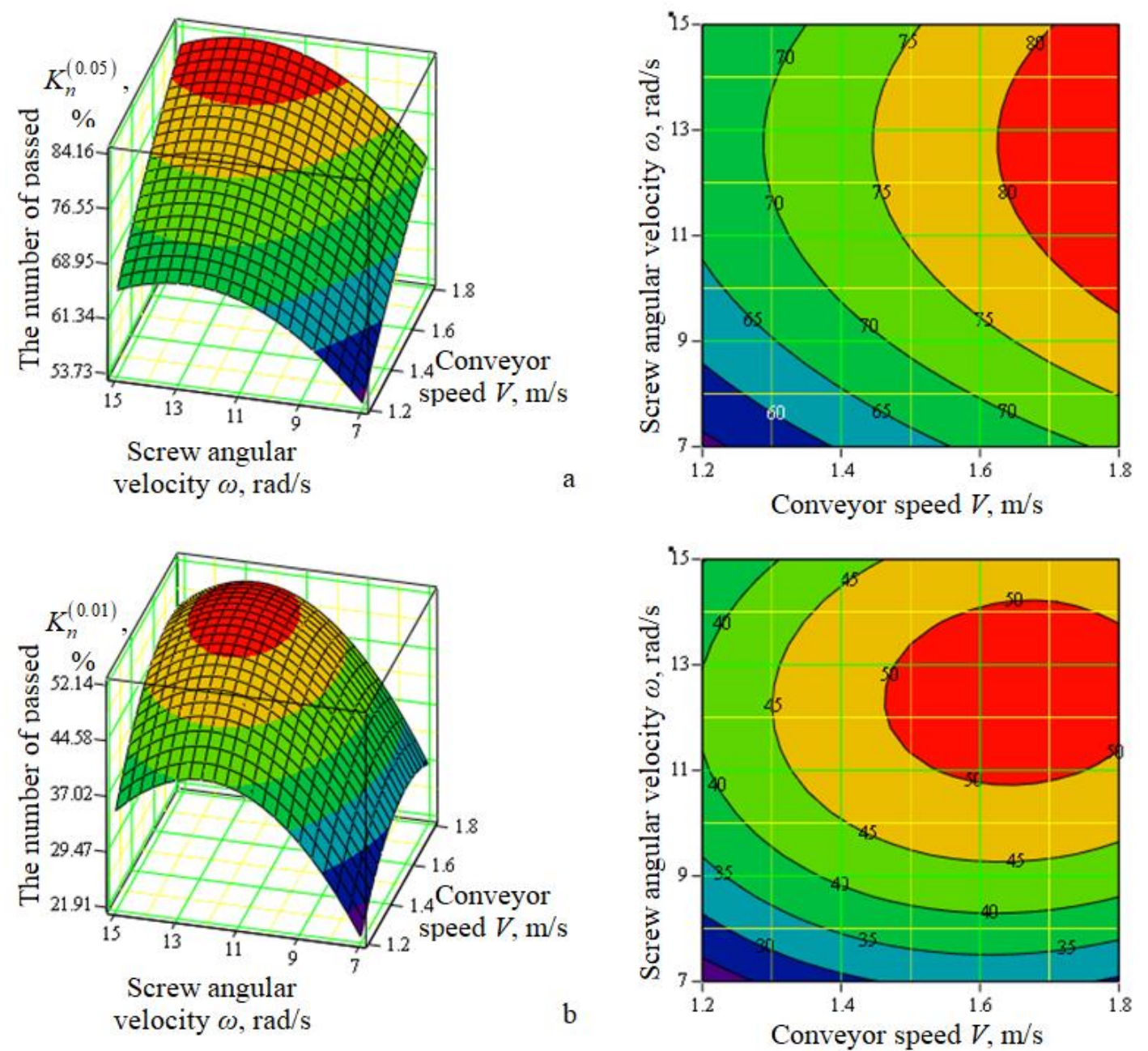

Figure 2. Dependency of the root tuber running through the device quantity from the transporter speed $V$ and worm screw angle speed when $H_{1}=0.05 \mathrm{~m}$ :

$\mathrm{a}, \mathrm{b}$ - respectively, for $d_{k}=0.05 ; 0.1 \mathrm{~m}$

- with feeding transporter speed $V \geq 1.5 \mathrm{~m} / \mathrm{s}$ and worm screw angle speed change within $11 \leq \omega \leq 14 \mathrm{rad} / \mathrm{s}$ (Fig. 2 b);

- with feeding transporter speed $V \geq 1.5 \mathrm{~m} / \mathrm{s}$ and worm screw angle speed change frames of $10 \leq \omega \leq 13 \mathrm{rad} / \mathrm{s}$ (Fig. $3 \mathrm{a}$ );

- with feeding transporter speed $V \geq 1.55 \mathrm{~m} / \mathrm{s}$ and worm screw angle speed change frames of $11 \leq \omega \leq 13 \mathrm{rad} / \mathrm{s}$ (Fig. $3 \mathrm{~b}$ ).

Further increase in transporter speed $V$ and worm screw angle speed $\omega$ to the maximum 
values leads to a reverse change in behavior character of $K_{n}^{(i)}$ - the quantity of tubers let through greatly decreases.

The results of regression equation analysis (3) established the following:

- optimization parameter of the averaged tuber diameter $d_{k}=0.15 \mathrm{~m}$ takes the max. value $K_{n . \max }^{(0.15)}=52 \%$ with the change of transporter speed within $1.5 \leq V \leq 1.6 \mathrm{~m} / \mathrm{s}$, worm screw pitch $T=0.5 \mathrm{~m}$, radial clearance gap $H_{1}=0.1 \mathrm{~m}$, worm screw angle speed within $10 \leq \omega \leq 13$ $\mathrm{rad} / \mathrm{s}$;

- optimization parameter of the averaged tuber diameter $d_{k}=0.1 \mathrm{~m}$ takes the max. value $K_{n . \max }^{(0.1)}=30 \%$ with the change of transporter speed within $1.5 \leq V \leq 1.6 \mathrm{~m} / \mathrm{s}$, worm screw pitch $T=0.5 \mathrm{~m}$, radial clearance gap $H_{1}=0.1 \mathrm{~m}$, worm screw angle speed $11 \leq \omega \leq 14 \mathrm{rad} / \mathrm{s}$.
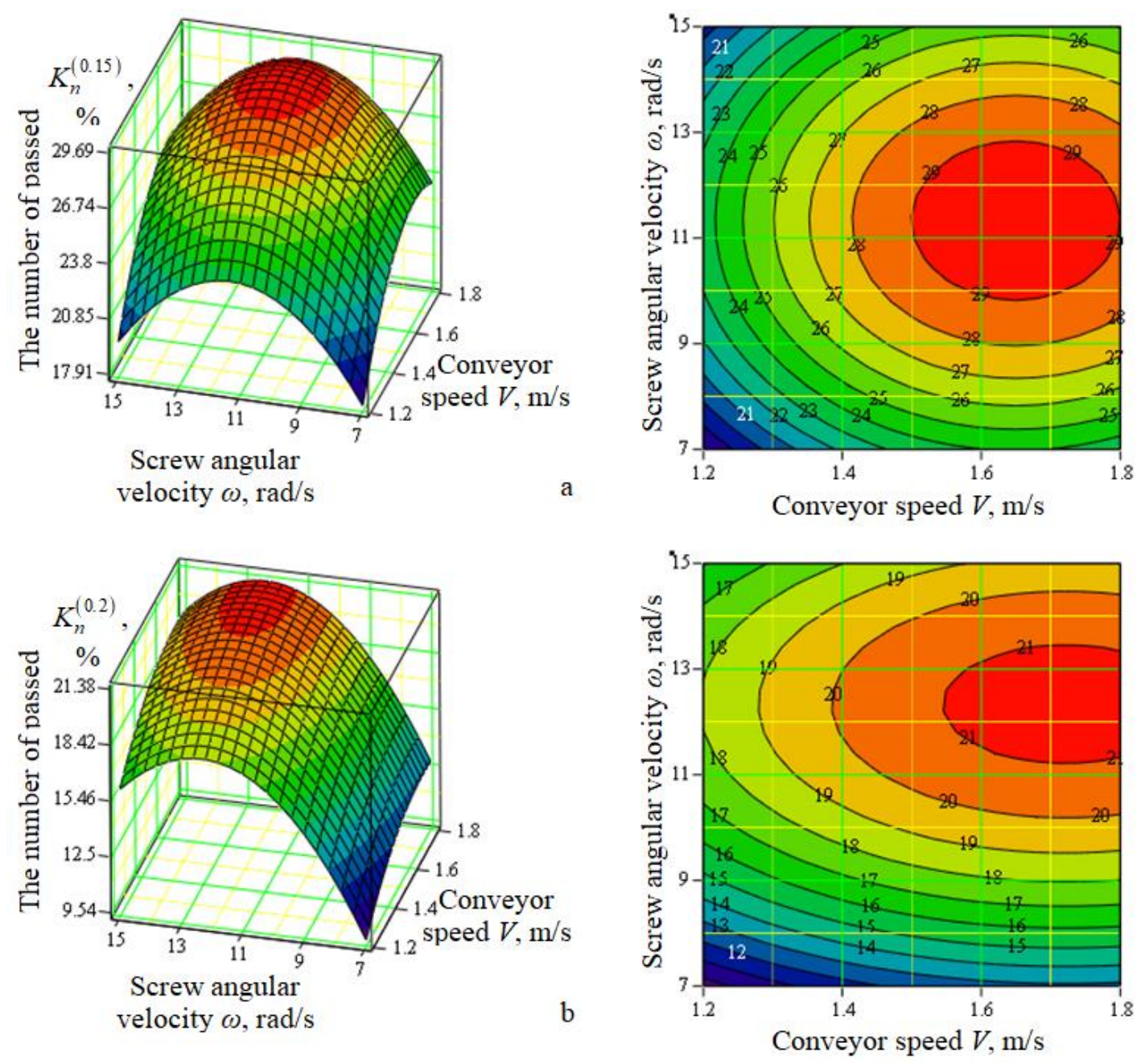

Figure 3. Dependency of the root tuber running through the device quantity from the transporter speed $V$ and worm screw angle speed when $H_{1}=0.05 \mathrm{~m} ; \mathrm{a}, \mathrm{b}-$ respectively, for $d_{k}=0.15 ; 0.2 \mathrm{~m}$

Conclusion. Accordingly, the obtained regression equations (1)-(4) characterize the change of the quantity of roots let through the worm screw to the creasing rollers depending on the main constructive-cinematic parameters of the combined root crop cleaner within:

- feeding transporter speed from $1.2 \mathrm{~m} / \mathrm{s}$ to $1.8 \mathrm{~m} / \mathrm{s}$; 
- worm screw pitch from 0.5 to $0.7 \mathrm{~m}$; $0.1 \mathrm{~m}$

- gap between the worm screw and the feeding transporter working branch from 0 to

- worm screw angle speed from $7 \mathrm{rad} / \mathrm{s}$ to $15 \mathrm{rad} / \mathrm{s}$.

Based on the graph-analytical analysis the rational parameters of the combined root crop cleaner have been established, with which the max. quantity of root tubers with averaged diameter of $0.1 \mathrm{~m}$ and $0.15 \mathrm{~m}$ can be achieved and is $52 \%$ and $29 \%$. At the same time, it has been established that the feeding transporter speed should be set within $1.5 \ldots 1.6 \mathrm{~m} / \mathrm{s}$, worm screw angle speed - from 10 to $14 \mathrm{rad} / \mathrm{s}$ with pitch of $0.7 \mathrm{~m}$ and radial clearance of $0.1 \mathrm{~m}$.

The research results will be used in the design of working bodies, which are designed to separate impurities from root crops, for example, chicory root crops, table, sugar and fodder beets.

\section{References}

1. Baranovsky V. M. Osnovni etapy ta suchasni tendentsii rozvytku korenezbyralnykh mashyn, Visnyk Ternopilskoho natsionalnoho tekhnichnoho universytetu. 2006. No. 11 (2). P. 67-75. [In Ukrainian].

2. Baranovsky V., Truchanska O., Pankiv M., Bandura V. Research of a contact impact of a root crop with a screw auger. Research in Agricultural Engineering. 2020. No. 66. P. 33-42. DOI: https://doi.org/10.17221/75/2017-RAE

3. Baranovsky V., Pankiv M., Dubchak N. Experimental research of stripping the leaves from root crops. Acta Technologica Agriculturae. Slovaca Universitas Agriculturae Nitriae. 2017. Vol. 20. No. 3. P. 69-73. DOI: https://doi.org/10.1515/ata-2017-0014

4. Pogorely L. V., Tatianko N. V. Sveklouborochnyie mashinyi: istoriya, konstruktsiya, teoriya, prognoz. K.: Feniks, 2004. 231 p. [In Russian].

5. Baranovsky V. M., Potapenko M. V. Theoretical analysis of the technological feed of lifted root crops. INMATEH: Agricultural Engineering, 2017. Vol. 51 (1). P. 29-38.

6. Mou X., Ou Y., Liu Q., Feng J., Li Y. Kinematic analysis and experiments of elastic dentations in process of sugarcane leaf sheath stripping. Agricultural Mechanics Report. Journal of Shandong Agricultural University. 2014. Vol. 2. P. 122-129.

7. Bulgakov V. M., Chernovol M. I., Sviren N. A. Teoriya sveklouborochnyih mashin: monografiya. Kirovograd, 2009. 256 p. [In Russian].

8. Bulgakov V., Nozdrovický L. The experimental research of combine harvesters. Research in Agricultural Engineering. Czech Academy of Agricultural Sciences. 2016. No. 62. P. 106-112. DOI: https://doi.org/10.17221/16/2015-RAE

9. Bulgakov V., Ivanovs S., Adamchuk V., Smolinskyi S. Theoretical studies of interaction of the drum cleaner with the sugar beet head, Research in Agricultural Engineering, 2018, No. 4. P. 143-150. DOI: https://doi.org/10.17221/104/2017-RAE

10. Bulgakov V., Ivanovs S., Pascuzzi S., Boris A., Ihnatiev Ye. Mathematical model of the cutting process of the sugar beet leafy tops without a tracer. INMATEH: Agricultural Engineering, 2019. Vol. 59 (1). P. 2938. DOI: https://doi.org/10.35633/INMATEH-59-04

11. Hevko R. B., Tkachenko R. I., Synii S. V., Flonts I. V. Development of design and investigation of operation processes of small-sclale root crop and potato harvesters. INMATEH: Agricultural engineering, 2016. Vol. 49 (2). P. 53-60.

12. Hevko R., Brukhanskyi R., Flonts I., Synii S., Klendii O. Advances in methods of cleaning root crops. Bulletin of theTransilvania University of Brasov. 2018. Series II. No. 11 (60). P. 127-138.

13. Hevko R. B., Tkachenko I. G., Rogatynskyi R. M., Synii S. V., Flonts I. V., Pohrishchuk B. V., (2019), Impact of parameters of an after-cleaning conveyor of a root crop harvester on its performance. INMATEH: Agricultural engineering, 2019. No. 59 (3). P. 41-48. DOI: https://doi.org/10.35633/INMATEH-59-05

14. Dubrovyn V., Golub G., Baranovsky V., Teslyuk V. Identifikatsiya protsessa razrabotki adaptirovannoy korneuborochnoy mashiny. Commission of motorization and energetics in agriculture. MOTROL, 2013. 15 (3). P. 243-255. [In Russian].

15. Špokas L., Adamchuk V., Holovach I., Prysiazhny V. Rozrobka vdoskonalenoho sposobu ochyshchennia koreneplodiv zbyralnoi mashyny. Zbirnyk naukovykh prats Vinnytskoho natsionalnoho ahrarnoho universytetu, seriia “Tekhnichni nauky". 2012. 11. I (65). P. 133-141. [In Ukrainian].

16. Storozhuk I. M., Pankiv V. R. Research results of harvesting haulm remnants of root crops. INMATEH: Agricultural Engineering, 2015. Vol. 46 (2). P. 101-108.

17. Žitnák M., Korenko M. Technical-economical indicators in the sugar beet transportation management. Research in Agricultural Engineering. 2011. No. 57. P. 63-71. DOI: https://doi.org/10.17221/29/2010-RAE 
18. Baranovsky V. M., Pidhurskij M. I., Pankiv M. R. Metodolohichni ta konstruktyvno-tekhnolohichni aspekty rozrobky adaptovanykh korenezbyralnykh mashyn. Visnyk Ternopilskoho natsionalnoho tekhnichnoho universytetu. 2014. 2 (74). P. 106-113. [In Ukrainian].

19. Baranovsky V., Skalskiy O. Digging of chicory root crops by a combined digger. Scientific Journal of TNTU (Tern.). 2018. Vol. 2 (90). P. 115-123. DOI: https://doi.org/10.33108/visnyk_tntu2018.02.115

20. Gritsay Yu., Baranovsky V., Marainenko S. Experimental studies of the homogeneity coefficient of crushed particles of root crops. Scientific Journal of TNTU (Tern.). 2019. Vol. 2 (94). P. 80-89. DOI: https://doi.org/10.33108/visnyk_tntu2019.02.080

\section{Список використаної літератури}

1. Барановський В. М. Основні етапи та сучасні тенденції розвитку коренезбиральних машин. Вісник Тернопільського національного технічного університету. 2006. № 11 (2). С. 67-75.

2. Baranovsky V., Truchanska O., Pankiv M., Bandura V. Research of a contact impact of a root crop with a screw auger. Research in Agricultural Engineering. 2020. No. 66. P. 33-42. DOI: https://doi.org/10.17221/75/2017-RAE

3. Baranovsky V., Pankiv M., Dubchak N. Experimental research of stripping the leaves from root crops. Acta Technologica Agriculturae. 2017. Vol. 20. No. 3. P. 69-73. DOI: https://doi.org/10.1515/ata-2017-0014

4. Погорелый Л. В., Татьяко Н. В. Свеклоуборочные машины: история, конструкция, прогноз. К.: Феникс, 2004. 231 c.

5. Baranovsky V. M., Potapenko M. V Theoretical Analysis of the Technological Feed of Lifted Root Crops. INMATEH: Agricultural Engineering, 2017. Vol. 51 (1). P. 29-38.

6. Mou X., Ou Y., Liu Q., Feng J., Li Y. Kinematic analysis and experiments of elastic dentations in process of sugarcane leaf sheath stripping. Agricultural Mechanics Report. Journal of Shandong Agricultural University. 2014. Vol. 2. P. 122-129.

7. Булгаков В. М., Черновол М. И., Свирень Н. А. Теория свеклоуборочных машин: монографія. Кировоград, 2009. 256 с.

8. Bulgakov V., Nozdrovický L. The experimental research of combine harvesters. Research in Agricultural Engineering. 2016. No. 62. P. 106-112. DOI: https://doi.org/10.17221/16/2015-RAE

9. Bulgakov V., Ivanovs S., Adamchuk V., Smolinskyi S. Theoretical studies of interaction of the drum cleaner with the sugar beet head. Research in Agricultural Engineering. 2018. No. 4. P. 143-150. DOI: https://doi.org/10.17221/104/2017-RAE

10. Bulgakov V., Ivanovs S., Pascuzzi S., Boris A., Ihnatiev Ye. Mathematical model of the cutting process of the sugar beet leafy tops without a tracer. INMATEH: Agricultural Engineering, 2019. Vol. 59 (1). P. 2938. DOI: https://doi.org/10.35633/INMATEH-59-04

11. Hevko R. B., Tkachenko R. I., Synii S. V., Flonts I. V. Development of design and investigation of operation processes of small-sclale root crop and potato harvesters. INMATEH: Agricultural engineering, 2016. Vol. 49 (2). P. 53-60.

12. Hevko R., Brukhanskyi R., Flonts I., Synii S., Klendii O. Advances in methods of cleaning root crops. Bulletin of theTransilvania University of Brasov. 2018. Series II. No. 11 (60). P. 127-138.

13. Hevko R. B., Tkachenko I. G., Rogatynskyi R. M., Synii S. V., Flonts I. V., Pohrishchuk B. V. Impact of parameters of an after-cleaning conveyor of a root crop harvester on its performance. INMATEH: Agricultural engineering, 2019. No. 59 (3). P. 41-48. DOI: https://doi.org/10.35633/INMATEH-59-05

14. Дубровин В., Голуб Г., Барановский В., Теслюк В. Идентификация процесса разработки адаптированной корнеуборочной машины. Commission of motorization and energetics in agriculture, MOTROL. 2013. № 15 (3). P. 243-255.

15. Шпокас Л., Адамчук В., Головач І., Присяжний В. Розробка вдосконаленого способу очищення коренеплодів збиральних машин. Збірник наукових праць Вінницького національного аграрного університету. Серія «Технічні науки». 2012. №. 11. Серія I (65). С. 133-141.

16. Storozhuk I. M., Pankiv V. R. Research results of harvesting haulm remnants of root crops. INMATEH: Agricultural Engineering, 2015. Vol. 46 (2). P. 101-108.

17. Žitnák M., Korenko M. Technical-economical indicators in the sugar beet transportation management. Research in Agricultural Engineering. 2011. No. 57. P. 63-71. DOI: https://doi.org/10.17221/29/2010-RAE

18. Барановський В. М., Підгурський М. І., Паньків М. Р. Методологічні та конструктивно-технологічні аспекти розробки адаптованих коренезбиральних машин. Вісник Тернопільського національного технічного університету. 2014. № 2 (74). С. 106-113.

19. Baranovsky V., Skalskiy O. Digging of chicory root crops by a combined digger. Scientific Journal of TNTU (Tern.). 2018. Vol. 2 (90). P. 115-123. DOI: https://doi.org/10.33108/visnyk_tntu2018.02.115

20. Gritsay Yu., Baranovsky V., Marainenko S. Experimental studies of the homogeneity coefficient of crushed particles of root crops. Scientific Journal of TNTU (Tern.). 2019. Vol. 2 (94). P. 80-89. DOI: https://doi.org/10.33108/visnyk_tntu2019.02.080 


\title{
УДК 631.356.26
}

\section{РЕЗУЛЬТАТИ ЕКСПЕРИМЕНТАЛЬНИХ ДОСЛІДЖЕНЬ ПРОХОДЖЕННЯ КОРЕНЕПЛОДІВ}

\author{
Віктор Барановський ${ }^{1}$; Віктор Теслюк²; Василь Лукач ${ }^{3}$; \\ Микола Ікальчик ${ }^{3}$; Анатолій Кушніренко ${ }^{3}$; Василь Кулик ${ }^{3}$
}

\author{
${ }^{1}$ Тернопільський національний технічний університет імені Івана Пулюя, \\ Тернопіль, Україна \\ ${ }^{2}$ Національний університет біоресурсів і природокористування України, \\ Київ, Україна \\ ${ }^{3}$ Відокремлений підрозділ Наџіонального університету біоресурсів $i$ \\ природокористування України «Ніжинський аграрний університет», \\ Ніжин, Україна
}

\begin{abstract}
Резюме. Підвищення технологічної ефективності роботи коренезбиральних збиральних машин, яка полягає у подальшому зменшенні забрудненості вороху коренеплодів домішками, $є$ актуальним завданням. Мета досліджень - обгрунтування конструктивно-кінематичних параметрів робочих органів очисника на основі аналізу отриманих емпіричних закономірностей кількості пройдених коренеплодів під шнеком до відминальних вальців. Наведено результати експериментальних досліджень кількості пройдених коренеплодів до відминальних вальців через зазор між шнеком і робочою гілкою подавального транспортера комбінованого очисника вороху коренеплодів. Описано експериментальну установку та методику проведення експериментальних досліджень прочесу переміщення макетних зразків коренеплодів, діаметр яких становив 0.05; 0.1; 0.15 і 0.2 м. Експериментальні дослідження проведено на основі реалізації планованих факторних експериментів типу ПФЕ $2^{4}$. Змінними факторами приймали швидкість руху транспортера (межі варіювання $1.2 \ldots 1.8 \mathrm{M} / \mathrm{c}$ ), крок шнека (межі варіювання $0.5 \ldots 0.7$ м); зазор між шнеком і транспортером (межі варіювання 0.05...0.1 м); кутову швидкість шнека (межі варіювання $7 \ldots 15$ рад/c). Наведено рівняння регресії, які характеризують залежність зміни кількості пройдених коренеплодів під инеком до відминальних вальців від основних параметрів комбінованого очисника та розмірних характеристик коренеплодів кормових буряків. Проведено аналіз графічних залежностей та встановлено значення параметрів і режимів роботи комбінованого очисника з умови забезпечення максимальної кількості пройдених коренеплодів. За результатами графо-аналітичного аналізу обгрунтовано раціональні параметри комбінованого очисника вороху коренеплодів, за яких кількість пройдених коренеплодів усередненого діаметра 0.1 м і 0.15 м є максимальною й становить відповідно 52\% і 29\%. При цьвому встановлено, щчо швидкість руху подавального транспортера перебуває у межах $1.5 \ldots 1.6 \mathrm{M} / \mathrm{c}$, кутова швидкість шнека - від 10 до 14 рад/с за кроку шнека 0.7 м і радіального зазору 0.1 м. Результати досліджень є подальшим кроком удосконалення методології розрахунку раціональних параметрів робочих органів коренезбиральних машин.
\end{abstract}

Ключові слова: шнек, подавальний транспортер, відминальні вальці, кількість пройдених коренеплодів. 